\title{
THE STATE POLICY OF SERVICE SECTOR DEVELOPMENT IN THE REPUBLIC OF KAZAKHSTAN
}

\author{
Assel Zhunussova \\ Academy of Public Administration under the President of the Republic of Kazakhstan \\ Raushan Dulambayeva \\ Academy of Public Administration under the President of the Republic of Kazakhstan
}

\begin{abstract}
Currently, the service sector is one of the fastest growing sectors in Kazakhstan, so the study of the service sector and the governmental intervention in it is essential, as it allows one to choose the instruments and limits of the support. The aim of the article is to study and describe the increasing role of the modern state policy of Kazakhstan in the development of the service sector, based on a study of the impact of public investment and government programs.

The paper shows the following results:

1. Implementation of state industrial programs in Kazakhstan leads to an increase in the services sector (expressed in the GDP structure and employment);

2. For Kazakhstan, there is still a high influence of public investments in the service sector, in contrast to Russia;

3. The highest rates of innovation activity in the service sector are in the fields associated with active government presence.
\end{abstract}

Keywords: service sector, government programs, public investment, service employment, Kazakhstan.

DOI: http://dx.doi.org/10.15549/jeecar.v6i1.255

\section{METHODOLOGY OF THE RESEARCH}

The theoretical and methodological basis was the Keynesian theory, various concepts of economic dirigisme, and theories of public administration presented in the literature review. One of the most effective tools for implementing state policy is government programs, including those aimed at developing the services sector.
The hypothesis is that the government intervention in the service sector in Kazakhstan was appropriate during the stage of the industrial sector formation and the transition to the post-industrial, and had positive effects on the development of the sector in the short run, as well as providing the groundwork for the future development of the service sector.

The study used the description method to explain the current situation in the sphere of 
state regulation of the service sector. To confirm the fact of the growing role of the state in the service sector, official program documents were used: the State Program of Industrial Development of the Republic of Kazakhstan for 2010-2014, the State Program of Industrial Development - innovative development of Kazakhstan for 2015-2019, and the program of development of the service sector until 2020. Also, to study the role of the state, the statistics on the inflows of public investment and their impact on GDP and employment in Kazakhstan was compared to Russia.

\section{LITERATURE REVIEW}

Modern studies, actualizing government intervention, consider that government policies supporting the service sector positively affect economic development. Uppenberg and Strauss (2010) and Pilat (2005) believe that investments, in general, have a positive effect on the development of the services sector. Nguyen and Trinh (2018) added that public investments are productive both in the longand short-term.

De Souza et al., who conducted a comparative analysis of the services sectors in the USA and Brazil, consider that economic policy to encourage service sectors is necessary to increase production and ensure employment (2016). Das and Raut (2014) believe that some timely government decisions to stimulate the service sector in India led to positive results. A study in Pakistan suggests the positive impact of foreign direct investment and government spending on the services sector (Zeb et al. 2017).

However, Doytch and Uctum (2018) do not agree with the affirmation of the positive impact of investment, considering that, for example, foreign direct investment in trade services has a negative impact on production, while having a slight positive impact on the services sector.

Moreover, according to Mitchell (2005), public spending on the provision of services should be reduced since the private sector can provide better services. Both assumptions are justified because the positive investment performance is felt only by strategically essential industries that are different for each country.

The priority of various service industries is also controversial. Edwards and Crocker (2001) state that investment in the field of information technologies is particularly favorable in the services sector, but Dzhangirov (2011) believes that higher priority should have investments stimulating the development of technologies in the field of transport and multimedia. A study by Teles and de Andrade (2004) concluded there was a positive result in the effectiveness and significance of public investment in the services sector using the example of primary education. Also, recent research in China has proven that it is necessary to invest income from natural resources into educational services (Sun et al., 2018).

Regarding the importance of program documents, research was conducted by Fiechert, who observed program documents in Germany and substantiated the state stimulation of German manufacturers in transport services (2017). Krivko believes that in Russia government programs along with methods of state influence are part of the economic mechanism of government services sector (2013). The development of policy documents stimulating the development of the service sector is an artificial but useful tool for many countries, especially for Kazakhstan, since technological modernization creates an employment problem that can be partially solved with the help of the development of the service sector.

Indeed, the service sector is also essential from the point of view of creating new jobs, since the introduction of computer technology already reduces the number of jobs (David, 2017). Gala et al., believe that the creation of new jobs in the service sector and manufacturing industries can provide economic growth (2018). The influence of modern technologies, in particular robotics, on increased employment in the services sector is still ambiguously positive, according to Qureshi and Syed (2014), and they urge the government's attention to the need to introduce industry-specific courses to increase human capital and minimize potential unemployment problems. 
Based on a literature review it was discovered that the process of stimulating the service sector is an essential condition of modern state policy. The specific feature of this article is to describe the influence of public policy on the sphere of services through program documents and public investments in the services sector (GDP and employment) in Kazakhstan.

\section{STATE REGULATION AND ITS IMPACT ON SERVICES}

Technical progress has become a part of the economic development of countries, progressively influencing the production processes. Modernization, application of innovations in the production, are release the productive forces and cause reorientation of them into the service production. The sphere of services in Kazakhstan includes the production of services in the areas of trade, transport, logistics, tourism, real estate market services, professional services, services in finance, insurance, information, communications, health, and education. The problem of government regulation is to choose between the ways to influence the services sector and to select the priority sectors.

In the period of modernization, the government can influence the sphere of services through the support of innovations, through public investment, and state programs. This article considers the state policy in the sphere of services through the organizational and target planning and targeted investment.

The priorities of the current public policy in Kazakhstan are to stimulate applied research and innovation aimed at the development, transfer, and adaptation of technologies - the state policy of Kazakhstan aimed to increase export-oriented and technological economy.

Since 2000, the modernization of the economy has been expressed in the orientation toward the structural reorganization of the economy of Kazakhstan, and in the search for ways to reduce the dependence of the economy on the export of raw materials. Modernization starting from 2010 has manifested itself in the diversification of the economy through the programs of industrial growth. Kazakhstan implements by two State programs on the accelerated industrial and innovative development of the Republic of Kazakhstan for 2010 - 2014 (hereinafter - SPAIID 2010-14), and the State program of industrial and innovative development for 2015-2019 (hereinafter - SPIID 2015-19), as well as by Program for the development of the services sector until 2020.

Table 1. The structure of GDP

\begin{tabular}{|l|l|l|l|l|l|l|}
\hline & \multicolumn{2}{l|}{$\begin{array}{l}\text { The period of } \\
\text { realization of the } \\
\text { necessity to avoid the } \\
\text { commodity } \\
\text { orientation }\end{array}$} & $\begin{array}{l}\text { The period of } \\
\text { implementation of } \\
\text { SPAIID 2010-14 }\end{array}$ & $\begin{array}{l}\text { The period of } \\
\text { implementation } \\
\text { SPIID 2015-19 }\end{array}$ \\
\hline Years & 2000 & 2005 & 2010 & 2014 & 2015 & 2017 \\
\hline $\begin{array}{l}\text { Agriculture, forestry and } \\
\text { fisheries }\end{array}$ & 8.0 & 6.3 & 4.5 & 4.4 & 4.8 & 4.4 \\
\hline Industry & 32.6 & 29.8 & 32.9 & 27.3 & 24.7 & 26.5 \\
\hline Mining industry & 13.0 & 15.8 & 19.5 & 15.2 & 12.7 & 13.3 \\
\hline Manufacturing industry & 16.5 & 12.0 & 11.3 & 10.2 & 10.1 & 11.2 \\
\hline $\begin{array}{l}\text { Electricity supply and water } \\
\text { supply }\end{array}$ & 3.1 & 2.0 & 2.1 & 1.9 & 1.9 & 2.0 \\
\hline Building & 5.2 & 7.8 & 7.7 & 5.9 & 6.0 & 5.6 \\
\hline Production of services & 48.3 & 52.0 & 51.7 & 54.8 & 59.4 & 57.5 \\
\hline Total GDP & 100.0 & 100.0 & 100.0 & 100.0 & 100.0 & 100.0 \\
\hline
\end{tabular}

Notes: * GDP structure excluding GVA and taxes on products and imports.

Compiled by the authors using the data of the Committee on Statistics for 2000-2017. 
The service sector in Kazakhstan has grown significantly since 2000 , from $48.3 \%$ of GDP in 2000 to $57.5 \%$ in 2017 . Its share is significant and reduces the influence of the industrial sector on the economy of the country. That is consistent with the theory of the formation of post-industrial society and technological advances. The benchmark of the state policy of Kazakhstan on industrialization and innovative development is the accurate benchmark of the economic course, which is reflected in an increase in the services sector over the years of the state programs (2010-2014; 2015-2018).

The structure of GDP is given in more detail in Table 1.

Stable growth in the share of services in GDP is a result of the dynamic development of service industries. From 2002 to 2010, the share of services in GDP was more than 50\%. Table 1 shows that during the period of the formation of the economy of Kazakhstan from 2000 to 2010, the most significant sector was the mining industry: $13 \%$ of GDP in 2000 , and $19.5 \%$ in 2010. The raw material orientation is a crucial problem of the economy of Kazakhstan, which the state is trying to solve by stimulating the manufacturing industry, industrialization, and the development of the service sector, through appropriate interrelated government programs.

Table 2. The share of employed in the service industries.

\begin{tabular}{|c|c|c|c|c|c|c|}
\hline & \multicolumn{2}{|c|}{$\begin{array}{l}\text { The period of } \\
\text { realization of } \\
\text { the necessity } \\
\text { to avoid the } \\
\text { commodity } \\
\text { orientation }\end{array}$} & \multicolumn{2}{|c|}{$\begin{array}{l}\text { The period of } \\
\text { implementation } \\
\text { of SPAIID 2010- } \\
2014\end{array}$} & \multicolumn{2}{|c|}{$\begin{array}{l}\text { The period of } \\
\text { implementation } \\
\text { SPIID 2015-2019 }\end{array}$} \\
\hline & 2001 & 2005 & 2010 & 2014 & 2015 & 2017 \\
\hline Wholesale and retail trade & $13.4 \%$ & $13.1 \%$ & $14.2 \%$ & $13.9 \%$ & $14.2 \%$ & $14.8 \%$ \\
\hline Transport and storage & $5.4 \%$ & $5.4 \%$ & $5.9 \%$ & $6.5 \%$ & $7.0 \%$ & $6.7 \%$ \\
\hline Accommodation and food services & $0.7 \%$ & $1.1 \%$ & $1.2 \%$ & $1.9 \%$ & $2.0 \%$ & $2.1 \%$ \\
\hline Information and communication & $1.4 \%$ & $1.3 \%$ & $1.3 \%$ & $1.8 \%$ & $1.7 \%$ & $1.7 \%$ \\
\hline Financial and insurance & $0.6 \%$ & $0.9 \%$ & $1.2 \%$ & $2.1 \%$ & $2.2 \%$ & $1.9 \%$ \\
\hline Operations with real estate & $0.7 \%$ & $1.2 \%$ & $1.6 \%$ & $1.0 \%$ & $1.1 \%$ & $1.8 \%$ \\
\hline $\begin{array}{l}\text { Professional, scientific and } \\
\text { technical activities }\end{array}$ & $1.2 \%$ & $1.6 \%$ & $1.7 \%$ & $1.8 \%$ & $2.5 \%$ & $2.6 \%$ \\
\hline $\begin{array}{l}\text { Activities in the field of } \\
\text { administrative and support } \\
\text { services }\end{array}$ & $1.7 \%$ & $1.8 \%$ & $1.9 \%$ & $2.2 \%$ & $2.6 \%$ & $3.1 \%$ \\
\hline $\begin{array}{l}\text { Public administration and defense; } \\
\text { compulsory social security }\end{array}$ & $3.7 \%$ & $4.2 \%$ & $4.4 \%$ & $5.2 \%$ & $5.3 \%$ & $5.3 \%$ \\
\hline Education & $7.8 \%$ & $8.8 \%$ & $9.5 \%$ & $11.0 \%$ & $11.4 \%$ & $11.7 \%$ \\
\hline Health and social services & $3.8 \%$ & $4.1 \%$ & $4.3 \%$ & $5.2 \%$ & $5.1 \%$ & $5.3 \%$ \\
\hline Arts, entertainment and recreation & $1.2 \%$ & $1.3 \%$ & $1.0 \%$ & $1.5 \%$ & $1.4 \%$ & $1.5 \%$ \\
\hline Other types of services & $1.7 \%$ & $1.4 \%$ & $1.6 \%$ & $3.2 \%$ & $3.1 \%$ & $2.9 \%$ \\
\hline All service sector & $\begin{array}{r}43.4 \\
\% \\
\end{array}$ & $\begin{array}{r}46.1 \\
\% \\
\end{array}$ & $49.9 \%$ & $57.3 \%$ & $59.6 \%$ & $\begin{array}{r}61.6 \\
\%\end{array}$ \\
\hline
\end{tabular}

Note: compiled by the authors based on the data of the Committee on Statistics for 2013-2017.

The service sector grew during the period of implementation of state programs, especially SPAIID 2010-14. Since 2010, the share of the mining industry declined to $13.3 \%$ in 2017 , while the share of manufacturing industry stayed at $10-11 \%$. The measures taken in the framework of modernization of the economy in the seven years have mainly affected the 
services sector, as the service industries are flexible and the first to react to the processes taking place in the economy. So, the volume of production of services in 2017 increased by $5.8 \%$ compared to 2010.

This was accompanied by an increase in the number of people employed in the service sector. This increase is associated with the release of labor from the spheres of industry, agriculture, and construction because of the introduction of technologies and innovations that replaced human labor. Another reason is the growth of the labor demand in the service sector, due to the increase in the production of services.

Table 3. EAEU countries program documents, which currently stimulated the service sector

\begin{tabular}{|c|c|c|}
\hline Programs & Year & Service sectors \\
\hline \multicolumn{3}{|l|}{ Armenia } \\
\hline Government program & 2016 & \multirow{2}{*}{$\begin{array}{l}\text { Tourism, transport, communications, IT, } \\
\text { education, health }\end{array}$} \\
\hline Government program & $2017-2022$ & \\
\hline The Agenda for Digital Transformation & $2018-2030$ & IT \\
\hline \multicolumn{3}{|l|}{ Belarus } \\
\hline $\begin{array}{l}\text { The comprehensive program for the } \\
\text { development of the service sector }\end{array}$ & $2006-2010$ & $\begin{array}{l}\text { Communications, insurance, bank, } \\
\text { advertising, goods transportation, real } \\
\text { estate services, tourism, health and sport }\end{array}$ \\
\hline $\begin{array}{l}\text { The national program of accelerated } \\
\text { development of services in the field of } \\
\text { information and communication } \\
\text { technologies }\end{array}$ & 2011-2015 & IT, science, professional education \\
\hline $\begin{array}{l}\text { The State Program for the Development } \\
\text { of the Digital Economy and the } \\
\text { Information Society }\end{array}$ & $2016-2020$ & IT, electronic, e-education, e-health \\
\hline $\begin{array}{l}\text { Program of social and economic } \\
\text { development }\end{array}$ & $2016-2020$ & Financial, transport, tourism \\
\hline \multicolumn{3}{|l|}{ Kazakhstan } \\
\hline $\begin{array}{l}\text { Program for the development of the } \\
\text { services sector until } 2020\end{array}$ & 2015-2018 & $\begin{array}{l}\text { Trade, transport, logistic, education, } \\
\text { health, financial, professional services, } \\
\text { real estate services }\end{array}$ \\
\hline $\begin{array}{l}\text { The state program of industrial and } \\
\text { innovative development for } 2015-2019\end{array}$ & 2015-2019 & Transport, IT, engineering, science \\
\hline Digital Kazakhstan & $2018-2022$ & Transport, logistic, e-trade, e-finance, IT \\
\hline Strategy 2025 & $2018-2025$ & $\begin{array}{l}\text { Education, health, IT, financial, } \\
\text { professional services, trade, and } \\
\text { engineering }\end{array}$ \\
\hline \multicolumn{3}{|l|}{ Kyrgyz Republic } \\
\hline 40 steps to prosperity & $2018-2023$ & Education, health, tourism, transport \\
\hline $\begin{array}{l}\text { Digital transformation program «Taza } \\
\text { Koom» }\end{array}$ & until 2040 & IT \\
\hline Sustainable Development Strategy & $2018-2040$ & $\begin{array}{l}\text { Science, education, health, tourism, IT, } \\
\text { social, finance }\end{array}$ \\
\hline \multicolumn{3}{|l|}{ Russia } \\
\hline Electronic Russia program & $2002-2010$ & IT, e-trade, \\
\hline Information society & $2011-2020$ & IT, communication, postal \\
\hline Digital economy & $2017-2030$ & IT, e-health, e-education \\
\hline
\end{tabular}

Note: compiled by authors 
There was steady growth in the level of employment in the labor market in the service sector: the share of employed increased from 43.3\% in 2001 to $61.6 \%$ in 2017. Kazakhstan has higher than the global level of employment in the service industries; the share of employed in the service sector in the world increased by $11.5 \%$, from $39.6 \%$ in 2001 to $51.1 \%$ in 2017 (World Bank). For the five years when state programs were implemented (2010-2015), the share of employment in the service sector increased by $9.5 \%$ compared to $2.7 \%$ in the previous period.

A significant proportion of the employed is in trade $-14.8 \%$ in 2017 . The share of employed in the education sector increased from $7.8 \%$ in 2001 to $11.7 \%$ in 2017, while in healthcare from $3.8 \%$ in 2001 to $5.3 \%$ in 2017 . The growth of employment in the services sector indicates the beginning of structural changes in the labor market, which can cause problems of unemployment in the future. The solution should be significant actions to regulate this problem on the part of the state; special attention should be given to measures aimed at retraining workers employed in industrial sectors into the services sector.

Kazakhstan is not the only country in the region engaged in stimulating the sphere of services through investment. The countries of the Eurasian Economic Union (EAEU) carry out some programs that directly or indirectly affect the services sector. Table 3 presents the program documents of the EAEU countries that contributed to the development of the service sector, as well as setting a modern trend in public policy. This unified trend can be interesting for further research, especially given the opinion of Yilmaz on the presence of the economic potential of the union (2017).

For the EAEU countries, the stimulation of communication services is inherent, and is dictated by the worldwide trend towards digitalization. Along with IT services, attention is paid to health and education services, as they are the basis for the development of human capital necessary for building a post-industrial society.

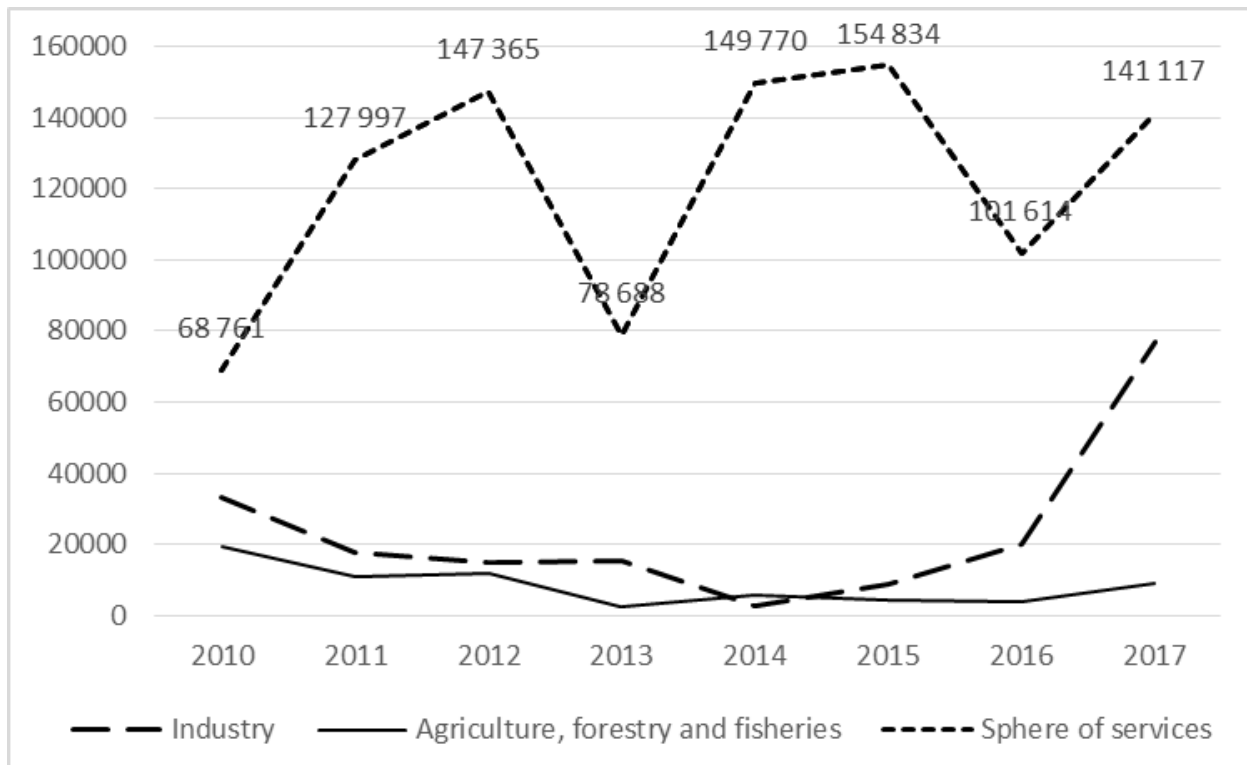

Figure 1. Public investment in the economy during 2010-2017, on millions of KZT

Note: calculated and compiled by authors based on the data of the Committee on Statistics for 2010-2017.

Differences in the policy pursued are the adoption by Belarus and Kazakhstan of a special program for the development of services. The
Kyrgyz Republic and Armenia are developing the services sector in general economic programs and strategies. Russia mainly 
supports the industry related services electronic technology and telecommunications. It should be noted that the countries also implemented sectoral programs in transport, education, and healthcare. Russia and Belarus also apply the practice of implementing annual targeted investment programs that are designed to solve problematic issues. The implementation of such programs allows seeing more detailed information about the objects and activities in which public investment flows.

Usually, the Kazakhstani Government invests in implementing certain strategically important

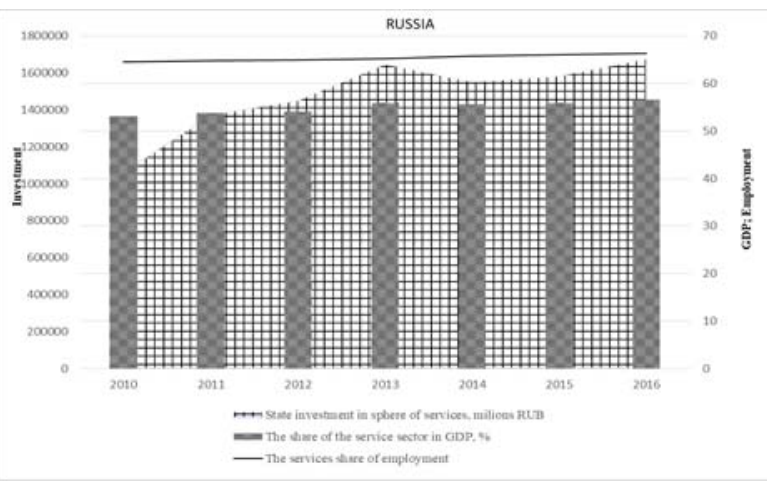

areas of public policy. Since the scope of services is wide enough, in Figure 1 large sums of funds allocated by the state are noticeable. There are also sharp declines in 2013 and 2016, caused by the decline in public investment in the transport and warehousing industry, which peaked in 2011 and 2014, during the implementation of Stage 2 of Kazakhstan's Transport Strategy, which was designed for intensive development.

Investments in the service sector from the government budget without considering investments in public administration, defense and compulsory social security

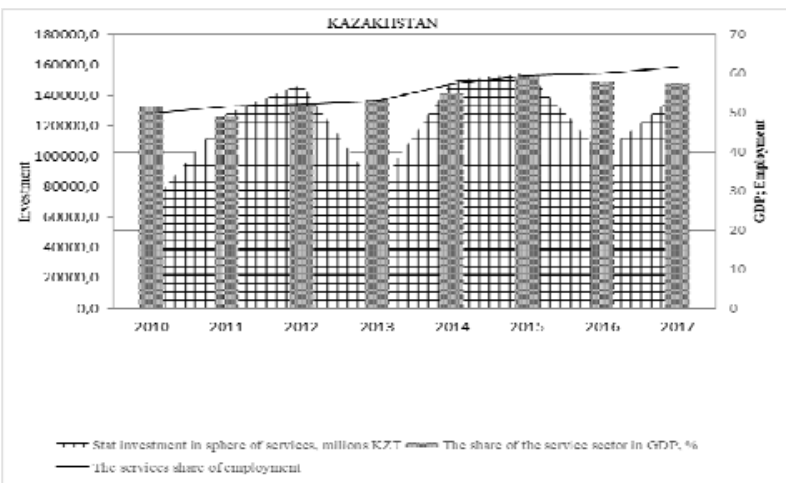

Figure 2. The influence of public investments on the share of the service sector in GDP and employment

Note: compiled by the authors based on the data of the World Bank, Federal State Statistics Services in Russia and the Committee on Statistics of the Republic of Kazakhstan. As noted before, public investment in services does not include investment in the public administration, defense, and compulsory social security

The dynamics of changes in GDP and employment indicate that the current state policy has significantly affected the service sector. To show the correct impact of public investment on services we considered the impact of changes in public investment on the level of employment in services and the share of services in GDP. The authors hold that public investment in the state administration, defense, and compulsory social security sector are direct and mandatory functions of the government; they are not aimed at stimulating services and, thus, are excluded from the value of the investments.

According to Figure 2, since 2010 the importance of services in the economies of Russia and Kazakhstan is continually increasing, which is shown in the structure of GDP and employment.

In Russia, the increases in public investment do not influence the stable growth in the service sector. The decline in public investment observed in 2012 and 2014 did not have a negative impact on the stability of the growth in the share of services in GDP and the employment market.

In contrast, in Kazakhstan, there is a noticeable impact of the public investments on the service sector in the short term, with an one-to-two year time lag. The growth of public investment in 2011 by $86.1 \%$ increased the share of services in GDP by $2.4 \%$, and the share of employed increased by $0.6 \%$ in 2012 . In 2014 , the increase in public investment by $90.3 \%$ 
compared to 2015, stimulated the growth in the share of services in GDP by $1.7 \%$ and increased the share of employed in the services sector by $2.3 \%$.

This observation highlights the importance of the state intervention for the development of the service sector in Kazakhstan. Also, the government mostly does not aim to get market benefits and usually stimulates strategically important industries, where the economic benefits are not so evident in the short run but capable of making the foundation for future development, especially through stimulation of innovations.

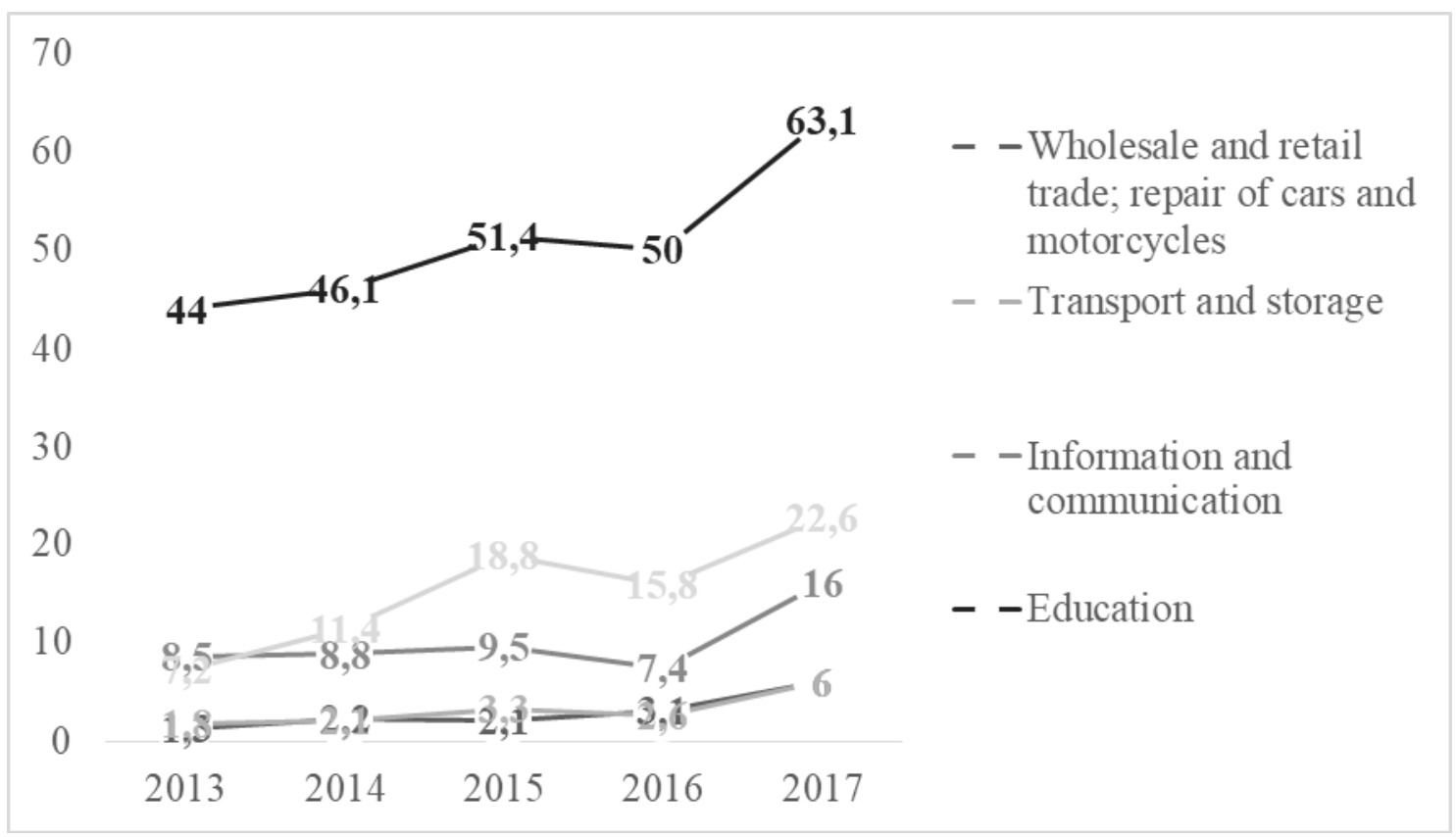

Figure 3. Innovative activity of enterprises (percent of innovative enterprises) by key industry Note: compiled by the authors based on the data of the Committee on Statistics for 2013-2016.

It does not exclude, however, the possibility that overall economic growth influenced employment and the structure of GDP, but it is worth noting that in 2011, the government actively stimulated investments, while employment and service share in GDP no longer returns to the 2010-2011s' level.

For instance, the public investment in the service sector increased twofold in 2017 compared to 2010, which influenced the innovative activity in the sphere regulated by the government. From Figure 3, noticeably significant innovative activity was in the education sector, where the indicator was $63.1 \%$ in 2017 , and the healthcare sector (22.6\%). In these service industries, the government is almost exclusively monopolistic. According to the Committee on Statistics, 11,716 public enterprises operate in the education sector, compared to 7,358 private, and 1,351 public enterprises operate in the healthcare sector, compared to 3,648 private ones.

Innovation activity in the sectors of trade, transport, and storage is lower compared to manufacturing, although the level of innovative activity of enterprises in the field of trade increased from 1.3\% in 2013 to 6\% in 2017, in transport and warehousing from $1.8 \%$ to $6 \%$ in 2017.

One of the results of active stimulating state policy is high innovation activity and the high potential of the education and healthcare sectors. According to $\mathrm{Wu}$ et al., stimulating innovations contributes to the transformation of developing countries, so government officials should pay attention to building capacity in innovation (2018). 


\section{REFERENCES}

40 steps to prosperity (2017). Retrieved June 21, 2018 from http://www.gov.kg/wpcontent/uploads/2017/08/40_rus.docx (Original work written in Russian)

Bell, D., (1973). The coming of Post-Industrial society https://www.os3.nl/_media/20112012/daniel_bell_-_the_coming_of_postindustrial_society.pdf

Committee on Statistics of Ministry of National Economy of the Republic of Kazakhstan (2017). Official web site, Official data for 2010-2017. Retrieved September 21, 2018

Comprehensive program for the development of the service sector, Belarus (2006).

Retrieved June 20, 2018 from https://economy.gov.by/ru/programma_raz vitia_sfery_uslug-ru/ (Original work written in Russian)

Das, L., \& Raut, R. (2014). Impact of changes in Service Sector in India in shaping the future of Business \& Society, Symbiosis Institute of Management Studies Annual Research Conference, 795-803.

David, B. (2017). Computer technology and probable job destructions in Japan: An evaluation, Journal of the Japanese and International Economies, № 43, pp. 77-87.

De Souza, K. B., de Andrade Bastos, S.Q., \& Perobelli, F.S. (2016). Multiple trends of tertiarization: A comparative input-output analysis of the service sector expansion between Brazil and United States, EconomiA. Vol. 17, pp. 141-158.

Digital economy 2017-2040 (2017). Retrieved June 21, 2018 from http://static.government.ru/media/files/9gF M4FHj4PsB79I5v7yLVuPgu4bvR7M0.pdf (Original work written in Russian)

Digital transformation program of the Kyrgyz Republic «Таза Коом». Retrieved June 21, 2018 from http://tazakoom.kg/site/concept/4 (Original work written in Russian)

Digital Kazakhstan (2017) Retrieved June 21, 2018 from

http://adilet.zan.kz/rus/docs/P1700000827 (Original work written in Russian)

Doycht, N. \& Uctum, M. (2018). Spillovers from
Foreign Direct Investment in Services: Evidence at Sub-Sectoral Level for the AsiaPacific. Journal of Asian Economics. https://doi.org/10.1016/j.asieco.2018.10.00 3

Edwards, M. \& Crocker, M. (2001) Major Trends and Issues. In: Innovation and productivity in service. OECD. pp. 7-15

Electronic Russia program (2002) Retrieved June 21, 2018 from http://economy.gov.ru/minec/activity/secti ons/fcp/doc1107343730375 (Original work written in Russian)

Federal State Statistics Services in Russia (2017). Official web site Statistical yearbook "Investments in Russia» (Original work written in Russian)

Fichert, F. (2017). Transport policy planning in Germany - An analysis of political, European Transport Research Review, pp. 9-28.

Gala, P., Camargo, J., Magacho, G., \& Rocha, I. (2018). Sophisticated jobs matter for economic complexity: An empirical analysis based on input-output matrices and employment data. Structural Change and Economic Dynamics. № 45, pp. 1-8.

Information society 2011-2020 (2014). Retrieved June 21, 2018 from http://government.ru/programs/218/events / (Original work written in Russian)

Keynes, M.J. (1935) The general theory of employment, interest and money.

Krivko, S.R. (2013). Theoretical basis of development management in the service sector in problematic regions of Russia, Izvestija Tulskogo gosudarstvennogo universiteta, No. 2-1, pp. 307-312. (Original work written in Russian)

Mitchell, D. J. (2005). The Impact of Government Spending on Economic Growth, Backgouder Published by The Heritage Foundation, pp. 1-18.

National program of accelerated development of services in the field of information and communication technologies, Belarus (2016). Retrieved June 21, 2018 from http://www.government.by/upload/docs/fil e4c1542d87d1083b5.PDF (Original work 
written in Russian)

Nguyen, C.T. \& Lua, T.T. (2018). The impacts of public investment on private investment and economic growth: Evidence from Vietnam, Journal of Asian Business and Economic Studies, №1, vol. 25, pp. 15-32.

Perroux, F. (1965). Leading industries and planning of economic growth, On Political Economy and Econometrics, pp. 463-486.

Pilat, D. (2005)/ Growth differentials in OECD countries: some reflections, Int Econ Econ Policy 2, 1-6.

Program of social and economic development 2016-2020 (2016). Retrieved June 21, 2018 from http://president.gov.by/ru/news_ru/view/ut verzhdena-programma-sotsialnoekonomicheskogo-razvitija-respublikibelarus-na-2016-2020-gody-15106/ (Original work written in Russian)

Program of the government of the Republic of Armenia (2016)

http://www.gov.am/files/docs/2033.pdf

Program of the government of the Republic of Armenia 2017-2022 Retrieved June 20, 2018 from http://www.gov.am/files/docs/2219.pdf

Qureshi, M.O. \& Syed R.S. (2014). The Impact of Robotics on Employment and Motivation of Employees in the Service Sector, with Special Reference to Health Care, Safety and Health at Work. Vol. 5, № 4, pp. 198-202.

Schwab, K. (2016) The Fourth Industrial Revolution. World Economic Forum.

Shumpeter, J. (2008) The theory of economic development. Moscow: Директмедиа Паблишинг

State program on forced industrial and innovative development of the Republic of Kazakhstan for 2010 - 2014 (2010). Retrieved March 13, 2018 from http://adilet.zan.kz/rus/docs/U100000958_ (Original work written in Kazakh and Russian languages)

Sun, H.P., Sun W.F., \& Kong Y.Sh. (2018). Natural resource dependence, public education investment, Petroleum Science № 3, Vol. 15, pp. 657-665.

Sustainable Development Strategy of the
Kyrgyz Republic 2018-2040. Retrieved June 21, 2018 from http://www.president.kg/files/docs/Files/pr oekt_strategii_final_russ.pdf (Original work written in Russian)

Teles, V. K. \& de Andrade, J. (2004). Public Investment in Basic Education and Economic Growth. SSRN doi.org/10.2139/ssrn.573301

The Agenda for Digital Transformation of Armenia. Retrieved June 20, 2018 from http://daf.am/pdf/digital_agenda_2018_203 0.pdf

The program for the development of the service sector in the Republic of Kazakhstan until 2020 (2014). Retrieved June 20, 2018 from http://adilet.zan.kz/rus/docs/P1400001378 (Original work written in Russian)

The State Program for the Development of the Digital Economy and the Information Society 2017-2020. Retrieved June 21, 2018 from

http://www.government.by/upload/docs/fil e4c1542d87d1083b5.PDF (Original work written in Russian)

The state program of industrial and innovative development of the Republic of Kazakhstan for 2015-2019 (2014). Retrieved March 13, 2018

http://adilet.zan.kz/rus/docs/U1400000874 (Original work written in Russian)

Uppenberg, K., \& Strauss, H. (2010). Innovation and productivity growth in the EU services sector, European Investment Bank.

World Bank data http://databank.worldbank.org/data/databa ses.aspx

Wu H., Xiong, J., Li, Q., \& Wei, T. (2018) Comparisons of catching-up among developed nations and developing countries, Journal of Eastern European and Central Asian Research, №2, Vol.5, pp. 9098.

Yilmaz, S. (2017) Eurasian Economic Union: A Regional Economic Hegemony Initiative, Journal of Eastern European and Central Asian Research, №2, Vol.4, 1-5.

Zeb, A. Hussain, K., Ahmad, U., \& Ajmair, M. (2017). Factors affecting the services sector 
growth in Pakistan: A time varying parametric approach, Journal of Economics Library №3, Vol. 4, pp. 388-395.

\section{ABOUT THE AUTHORS}

Assel Zhunussova, email: aselzhunusova88@gmail.com

Mrs. Assel Zhunussova is a doctoral student at the Academy of Public Administration under the President of the Republic of Kazakhstan. She is also an employee of the Committee of Statistics at the Ministry of National Economy of the Republic of Kazakhstan. Her research interests are in the service sector and public policy.

Dr. Raushan Dulambayeva possesses a doctoral degree in economic science. She is the professor in the Institute of Management, Academy of Public Administration under the President of the Republic of Kazakhstan. Her current research interests are in economic policy, regulatory impact analysis and instrumental research methods. She teaches modern economic policy, financial markets, applied macroeconomics, and applied economics. 